\title{
Supplementary Table 1:
}

List of all DNA sequences used in the study

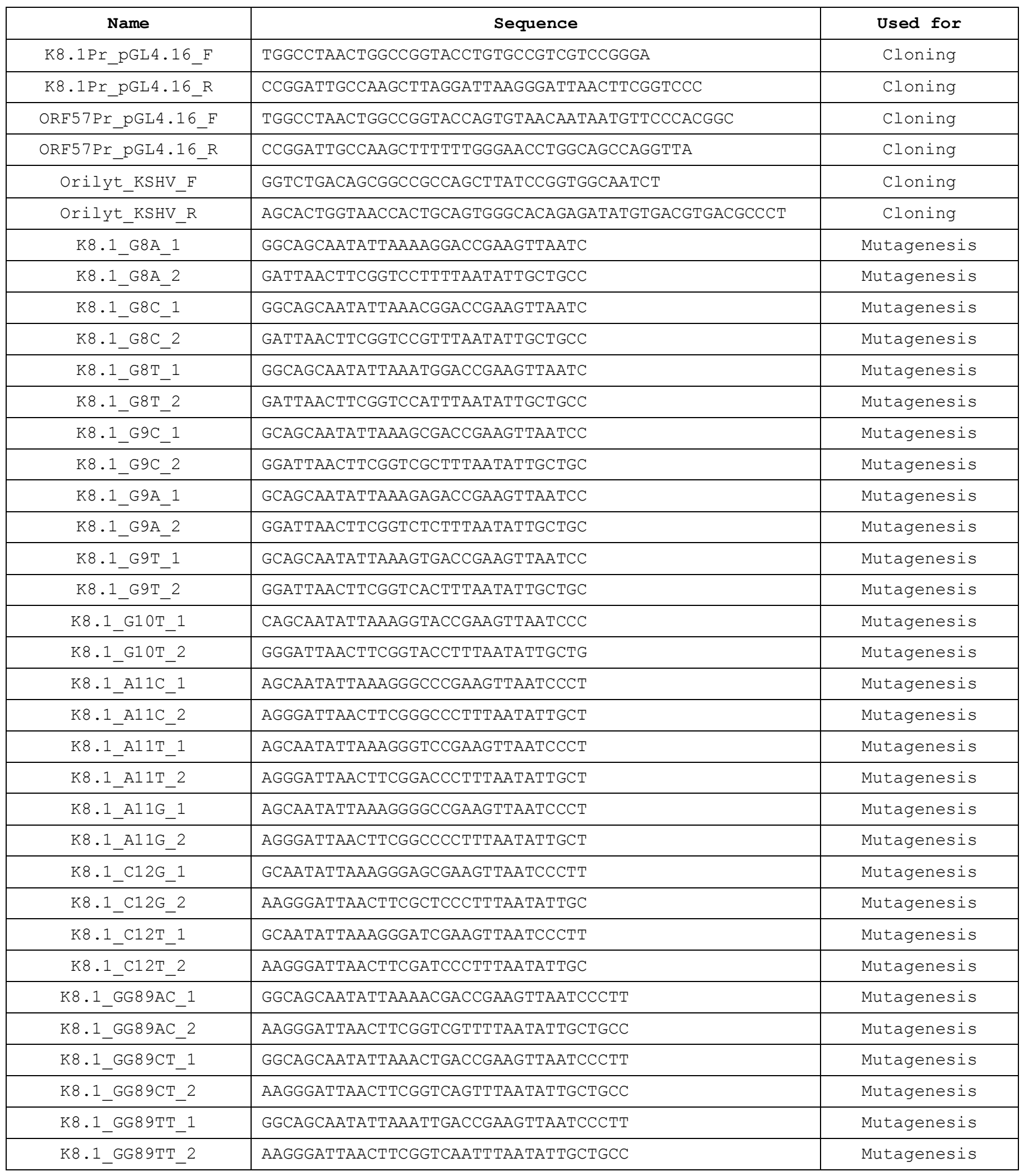




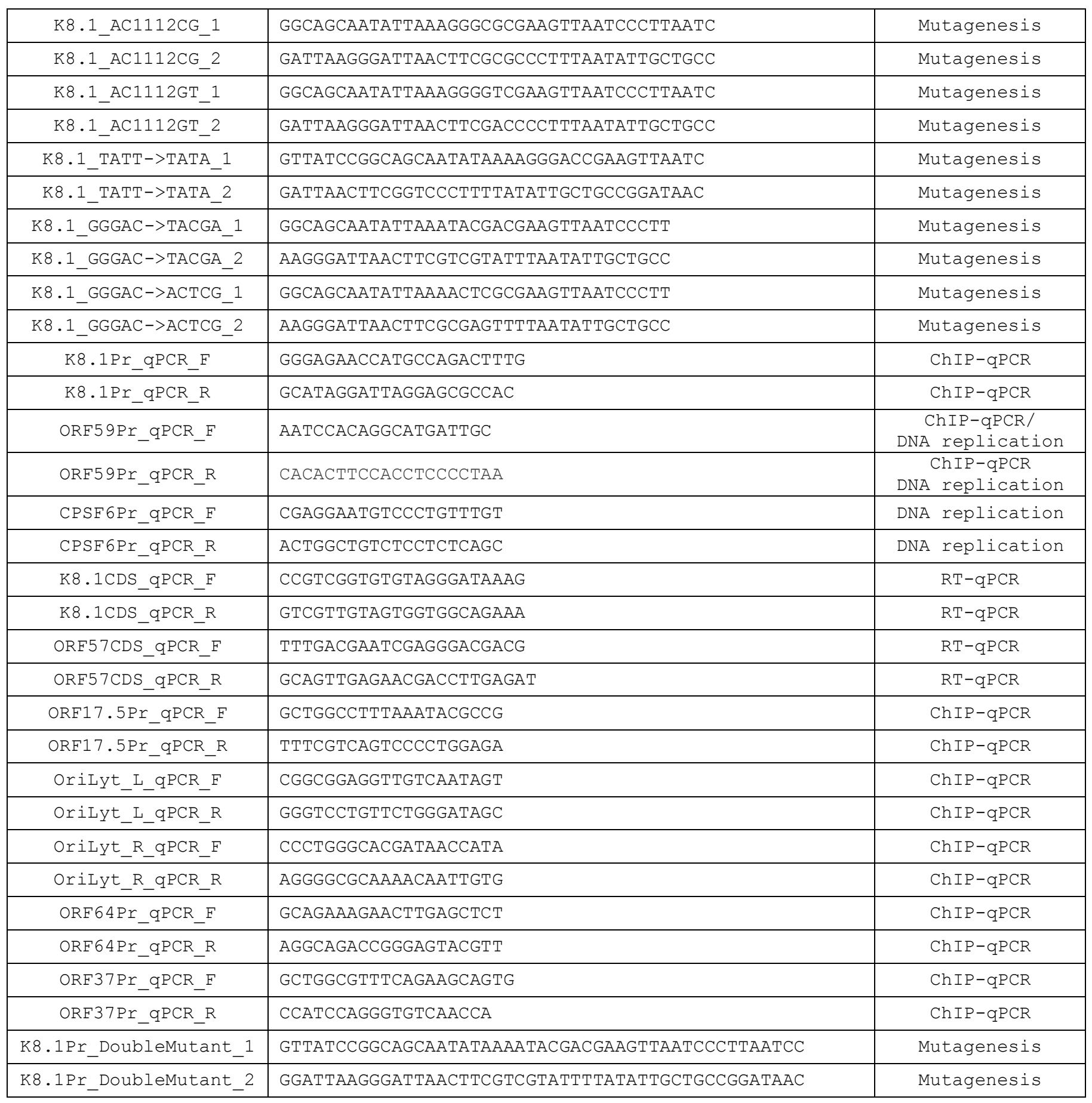

